\title{
Understanding Riverine Urbanism in Kalimantan through Diachronic Approach: Case Study of Lanting Settlements in Sintang, Indonesia
}

\author{
Mira Sophia Lubis, Dalhar Susanto, Triatno Yudo Harjoko \\ Department of Architecture, Faculty of Engineering, Universitas Indonesia, Depok, Indonesia \\ Corresponding e-mail: miralubis@gmail.com,mira.sophia@ui.ac.id
}

Article info:

Received: 24-8-2021, Revised: 13-9-2021, Accepted: 25-10-2021

\begin{abstract}
Famous for its large rivers, Kalimantan is one of the islands in Indonesia that is characterized by a river-cultured society, where lanting or floating dwelling is one of various types of river settlements that represents a unique but also complex relationship between man and river. Despite their existence being in line with the historical development of river cities in Kalimantan, today's urban lantings have come to be stigmatized as slums, due to society's biased perspectives, and the dominance of the planning paradigm that is oriented towards "modern" land-based urban planning. Using the qualitative historical analysis method in the case study of lanting dwellings in Sintang, West Kalimantan, this study interprets the analytical dimensions of the complex relations between space, power and resources, which changes over time. Exploring the political-economic and ecological history shows the long journey of lanting's existence that gave understanding of today's lanting conditions, as well as understanding about the development of the cities themselves. This study concludes that the concept of river cities or waterfront cities in Kalimantan should be understood in a broader sense, beyond merely aesthetic and environmental considerations. Riverine settlement has deep historical roots in many Kalimantan cities and also represents complex relationships between city-hinterland and river-related urbanization process under the political-economic and ecological changes. Thus, consideration of the diachronic aspects of city-river relations should be an important basis for planning future Kalimantan cities.
\end{abstract}

Keywords: river/river-based urbanism, diachronic, lanting (floating house), Sintang, West Kalimantan

\section{Introduction}

Kalimantan is the world's third-largest island, boasting hundreds, if not thousands, of rivers and tributaries (see Figure 1). Among Indonesia's main largest rivers (Table 1), the Kapuas River in West Kalimantan, 1,143 kilometers in length, is the longest river on the entire island (Khee Giap Tan et al 2015). During the 19th and early 20th centuries, the Kapuas River and other major rivers in Kalimantan became the main transportation networks, connecting coastal areas with the interior of this vast island (Heidhues 2003, Derek 2001). The rivers and their tributaries functioned as waterways that connected human settlements and trading centers in major rivers with agricultural fields and sources of forest products in smaller branches (Schliesinger 2017). Therefore, in the past, local authorities competed with one another to establish trade monopolies and be able to control trade routes (Boomgard 2007, Listiana 2012).

For centuries, lanting, or floating houses have been built and developed by the people of Kalimantan, together with stilt houses, the other type of traditional settlement (Evers, 2015). They proliferate randomly in Kalimantan's major rivers, such as the Kapuas, Kahayan, Barito, and Mahakam, integrated with a network of rivers and tributaries that are almost entirely navigable (see Figure 3). Historical records indicate that in the past, lanting communities 
played an essential role in political and economic processes in settlements ranging from the Kapuas River downstream to upstream, where Sintang, one of these settlements which is located in the middle of Kapuas River channel, played important role as trading pocket in the interior region (see Figure 2). Along with the growth of Sintang, started from the kingdom era to the present day, which is characterized by its dynamic social, economic, and political changes, lanting settlement has always existed and has become an inseparable element of the city.

However, the river's ecological condition, once the vital base for lanting, is no longer stable. Today, lanting-dwellers must live amid declining river conditions, including pollution (due to massive plantation activities, illegal gold mining, and the use of poison for fishing activities), extreme river currents and tides (due to deforestation in the upper reaches of the river), as well as poor environmental stewardship in the form of people throwing garbage into the river.

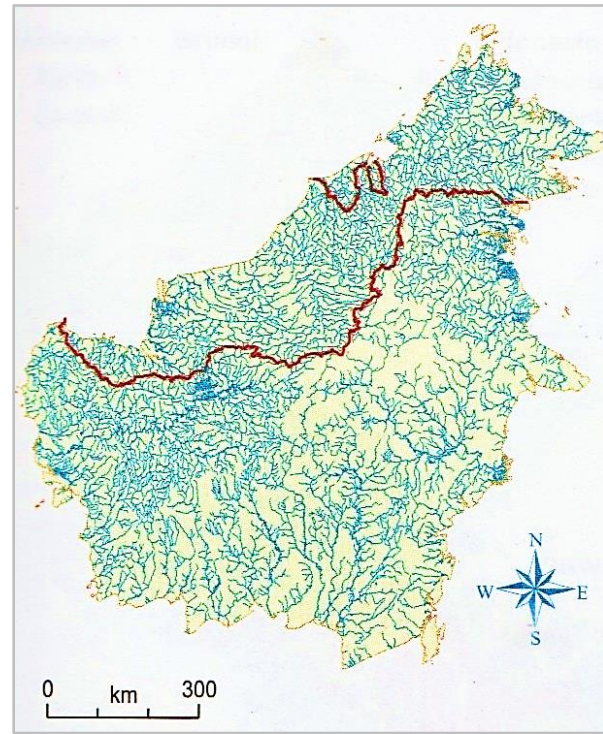

Figure 1: Kalimantan's densed river networks (Source: Koninck et.al, 2011)

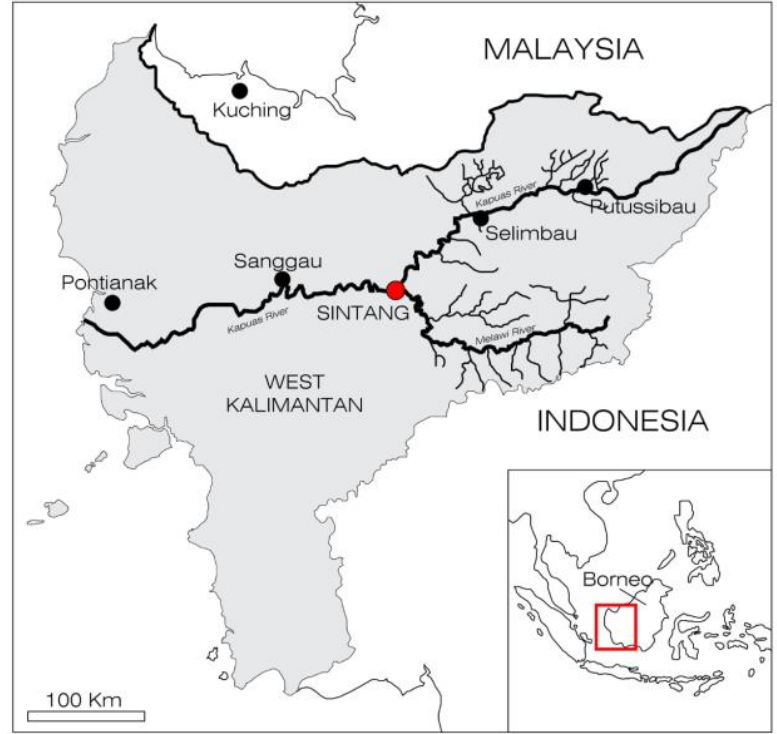

Figure 2: Sintang, a city in West Kalimantan located at the junction of the Kapuas and Melawi Rivers

Tabel 1. List of Indonesia's largest rivers (Source: Wikipedia, 2021)

\begin{tabular}{rlcc}
\hline No & \multicolumn{1}{c}{ Name of River } & Length $\mathbf{( k m )}$ & Location \\
\hline 1 & Kapuas & 1.143 & Kalimantan \\
2 & Mahakam & 920 & Kalimantan \\
3 & Barito & 900 & Kalimantan \\
4 & Batanghari & 800 & Sumatra \\
5 & Musi & 750 & Sumatra \\
6 & Mamberamo & 670 & Papua \\
7 & Bengawan Solo & 600 & Java \\
8 & Kahayan & 600 & Kalimantan \\
9 & Digul & 525 & Papua \\
10 & Indragiri & 500 & Sumatra \\
\hline
\end{tabular}

In several cases of urban riverine settlements in Kalimantan cities, such as in Banjarmasin, Balikpapan and Samarinda, these lantings are getting stigmatized as slum, as is the case of riverbank kampungs in big cities in Java, where residents are forcibly evicted and their 
settlements cleared for reasons of flood mitigation or simply to fulfill the imagination of a 'green waterfront global city' (King \& Idawati 2010, Hellman 2018). The character of river-cultured cities that has been firmly entrenched for decades is slowly disappearing from the faces of Kalimantan's cities, although floating villages still persists to this day.

This paper aims to comprehensively explore the existence of riverine settlements in the constitution of urban society in Kalimantan. As a case study, lanting settlement in Sintang, the capital of Sintang District, West Kalimantan Province, was investigated, as they remain active despite rapid urbanization of the city. Located in the middle of the Kapuas river channel (approximately $500 \mathrm{~km}$ from the upstream and $500 \mathrm{~km}$ from the downstream), Sintang is also at the confluence of two major rivers, The Kapuas and The Melawi rivers. Growing from the river's edge, the present Sintang (with approximately 83,000 inhabitants) still maintains its riverine culture in the form of floating houses or lanting as its legacy of the past, at a time when rivers played important roles as main routes for political and economic activities, as well as sources of livelihoods (See Figure 4).

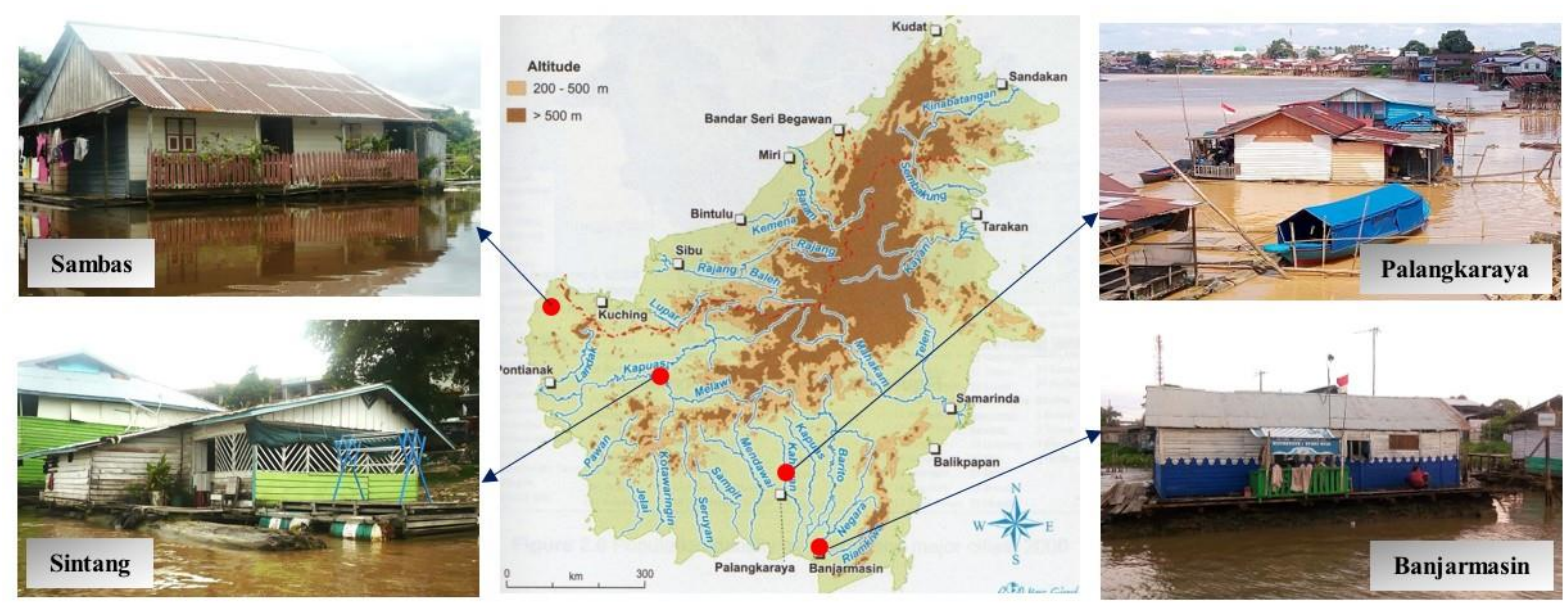

Figure 3. Lanting in various river cities in Kalimantan (Source: personal documentation, 2017-2019)

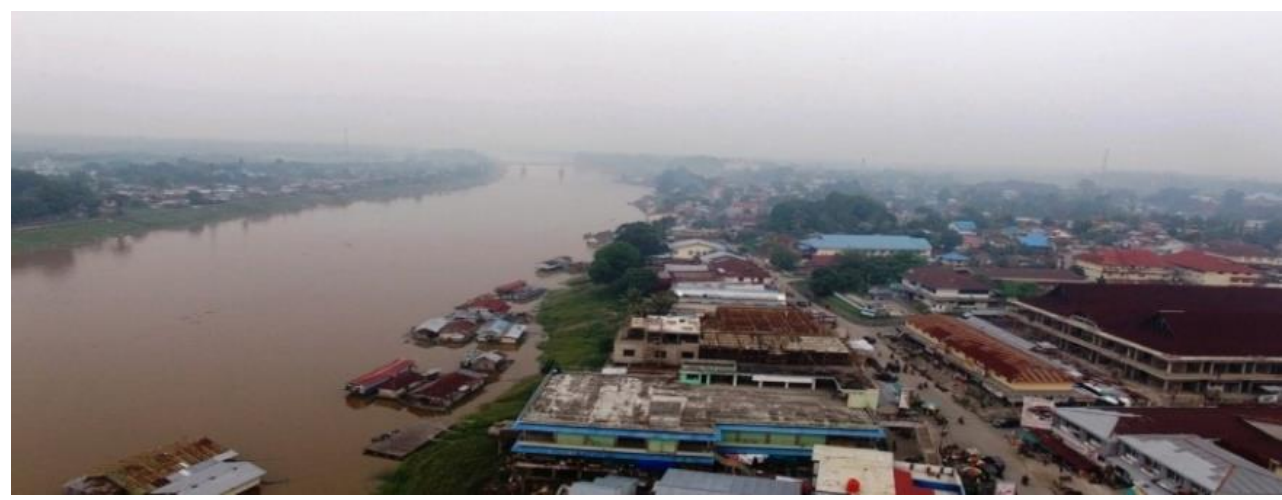

Figure 4. Aerial view of Sintang City (Source: personal documentation, 2019)

\section{Approach and Methods}

In this study, urban spaces are seen as a representation of the dynamics and complex nexus between space, power and resources. Lefevbre (1991) uses the concept of production of space, in contrast to the common view of space as 'space in itself', which contains an understanding of space which is fundamentally tied to social reality, or as Soja (1980) termed it as socio-spatial dialectic. In this regard Lefebvre also recognizes the importance of life 
experience, in the social production of space. For Lefebvre, the dominance of capitalism in the western world is parallel to the production of abstract space through social fragmentation, homogenization and hierarchicalization (Ibid, 1991). One of the solutions he proposed to destroy the "abstract space" constructed by capitalism and the state is to propose what he calls the "right to the city". Etienne Balibar (2007) interprets the right to the city as an extension of justice and equality for the citizens of the city. By talking about the right to the city, we talk about the city as a polis, as a political collectivity in which all citizens have the opportunity and equality to realize themselves fully in order to achieve happiness. The right to the city is a citizen's claim to be known and acknowledged as the creator of various social relations, the citizens as the rulers of their social space and to live differently in it.

Using the qualitative historical analysis or diachronic ${ }^{1}$ method in the case study of lanting settlements in urban setting, with various techniques of data collecting such as in-depth interviews with participants (mostly the lanting dwellers, and later academics, community leaders, and historians), participant observation, literature review and analysis of historical documents, this study produces a diachronic picture of the lanting settlements along with the process of Sintang's urbanism, through understanding the lanting and the city as products of the complex relationship between space, power and resources.

\section{Results and Discussions: Coexistence of Lanting Over Time: A diachronic picture}

To provide a well-structured diachronic picture, we classified historical data obtained from survey results with the help of extant theory of urban development classification. Regarding the historical development of cities, few scholars have sought to explain the evolution of the development of Indonesian cities. Wertheim (1950) divided the development of Indonesian cities into four stages: the Old Indonesian Town, the Indische Town, the Colonial Town, and the Modern Town (Wertheim 1950), while Keyfitz (1961), chronicled the stages of evolution in Indonesian cities into Pre-Colonial, Colonial, and Independence periods. These classifications are more or less the same except that Wertheim's Indische and the colonial city periods were merged to create one "Colonial" period in Keyfitz's classification. In this study, the Keyfitz classification was chosen, considering there are not enough differences between the Indische period and the Colonial Town period to be relevant in the case of Sintang city.

\subsection{Pre-colonial era (before 1855)}

Pre-colonial era (before 1855)

Sintang was once a kingdom dating back to the days of Hindu influence on Kalimantan that later turned into Islamic territory, which was estimated to be established in the 17th century. The word "Sintang" itself came from "Senentang," which means the intersection of two rivers (Fienieg 2007). It was once known as the most prominent kingdom in the interior of West Kalimantan. Before the Dutch came, the kingdom was known to have made various efforts to conquer other territories both upstream and downstream of the Kapuas River, until it reached its pinnacle towards the end of the 18th century. (Listiana 2012).

The river was vital, with the designation of the kingdom's borders even referring to river paths (Sjamsuddin, 2013). The heavy forest cover in the past meant that the distribution and transportation of bulky goods was limited to the river systems and a number of routes through the mountains in the interior. The rulers at the river mouth controlled the import-export trade and acted as gatekeepers for the entire system. The rulers along the river acted as intermediaries between the main port in the river mouth with commodity producers in the

\footnotetext{
${ }^{1}$ Concerned with the way in which something has developed and evolved through time. (Source: Oxford Dictionary)
} 
inland's forests and river's upstream, by imposing taxes on goods that crossed their territory. These small kingdoms organized the people who settled along the river system in the interior into networks of trading and collecting stations that facilitate this trade. (Christie 1995). This is similar to what was described by Bronson (1978) as the river-basin hypothetical model to economic systems in Southeast Asia, and Airress (2003:90-91) which stated that the "spatiopolitico conception of the downstream versus upstream stretches of rivers illustrates the importance of ecological cognition in traditional Malay political culture", where the words 'hulu' and 'hilir' are defined as upstream and downstream.

Regarding the early existence of lanting, the role of ethnic Chinese settlers in the Sintang kingdom was very significant given that it was predominantly they who had occupied the lanting, although the Malays and Dayaks have used lanting for purposes related to bathing, washing, and fishing. Chinese people played an important role in introducing the culture of living on the water in houseboats (Ooi 2004, Tagliacozzo and Chang 2011). Generally, Chinese people from mainland China who migrated to Kalimantan were not wealthy traders in their home regions. They were mostly small traders and underprivileged workers, so they could not afford to buy land, and were forced to live in lanting houses or houseboats (Author's interviews, 2018).

The first arrival of the Chinese to West Kalimantan was in the mid-18th century to work as gold miners, and later, to become traders (Heidhues, 2003). Many of them settled on the coast of West Kalimantan, and a small number went inland through river channels. In Sintang, the number of Chinese in the 19th century was estimated to be no more than around 1,700 people, or only 2.5 percent of the Sintang population (Fienieg, 2007). They lived in an area now called the Sungai Durian, which, in the past, was called the "Pasar Cina" or Chinese Market (Rahmayani 2018), occupying lanting houses, which also functioned as their shops. The size of the lantings in the past was bigger than those seen today. Traditionally, they could reach 78 meters in length, consisted of several bedrooms, a living room, and a shop, and would be inhabited by one big family (Author's interviews, 2018).

In this period we can see that the river represented power and hegemony of the rulers, and as an important economic network connecting the inland area (as producer of forest commodities) with the global trade, where the kingdom, the Chinese migrants, and the Dayaks and Malays as locals, are actors that come together to form the network.

\subsection{Colonial era (1855-1945)}

\section{Dutch East Indies Era (1855 - 1942)}

The first arrival of the Dutch in Sintang was in February 1822 (Veth 2017). The Sintang kingdom submitted and was forced to sign a contract to recognize the Dutch as their rulers. From the Dutch perspective, the purpose of the deal was to expand Dutch power and trading activities on Kalimantan (Oostindie 2008). Nevertheless, in 1827, the Dutch left Sintang due to unfavorable conditions and because Sintang was too far from the center of government in Java. Sintang was left free for 30 years until the Dutch came back again to enter into a second agreement in 1855 to mitigate perceived threats to their trading activities in West Kalimantan from the British influence in Sarawak region (Veth 2017, Sjamsuddin 2013, Listiana 2012).

Since the Dutch occupied an empty area on a riverbank at Tanjung Puri, sitting directly across the river from the Keraton Sintang, it became easy for they and the Sintang kingdom to collect taxes from passing boats headed in either direction (Listiana 2012). For this purpose, some lantings were used as surveillance posts by both Royal and Dutch authorities (Author's interviews, 2018). 
Sintang grew to become an essential economic center in the interior of West Kalimantan. Merchant boats and floating markets crowded the city at the junction of two major rivers. In 1895 , the population of Sintang was estimated at 26,600, consisting of 15,600 Dayaks, 10,000 Malays, more than 100 Bugis, 650 Chinese, and a smaller assortment of people from the east (Enthoven, 1903). The Chinese traders became the leading agent in the process of upstreamdownstream economic integration on the Kapuas River, together with the Malays and Dayaks.

Along with the decline of the gold mining era in the late 19th century, many Chinese miners on the coast of West Kalimantan turned into merchants in the interior (Rahmayani et al. 2018). They became agents for large companies on the coast and the Kapuas estuary. By using various types of river transportation, such as boats, canoes, steamboats, and houseboats, they traveled hundreds of kilometers inland. In inland settlements, especially in Sintang, they built lanting as dwellings and places of commerce. Along the banks of the Kapuas River, Chinese settlements were marked by the presence of boats, lanting houses, and floating markets. The Chinese had an essential role in colonial economic activity, especially in terms of tax revenues for the Dutch ruler.

Until the end of the Dutch occupation in Indonesia, the regulations implemented in Kalimantan were relatively the same as those from previous periods. The establishment of the Dutch Ethical Policy in the early 1900s, which included the improvement of health, education, and welfare of colonized countries had minimal impact on Kalimantan owing to its vast and difficultto-reach areas (Cleary \& Eaton 1992). However, during this time, the influence of Christian missionaries in the interior of Kalimantan had started to grow, evidenced by their ability to convince locals to adapt, and through the construction of community service facilities, such as floating schools and floating hospitals, as seen in Figure 6 (Author's interviews, 2017).

What distinguishes this period from the previous one is that, (1) There were two rulers (the Dutch and the kingdom) who controlled the economy and the river network, and (2) The Dutch gave higher status to Chinese migrants by officially granting them the right to manage their own affairs through the entire Sintang region. At the district level, Chinese leaders were referred to as Kapitan der Chineezen, while at the sub-district level, they were called lothay(s) (Sumarman, 2010). Chinese traders were considered to have played an important role in advancing the economy of the colonial government in this region.

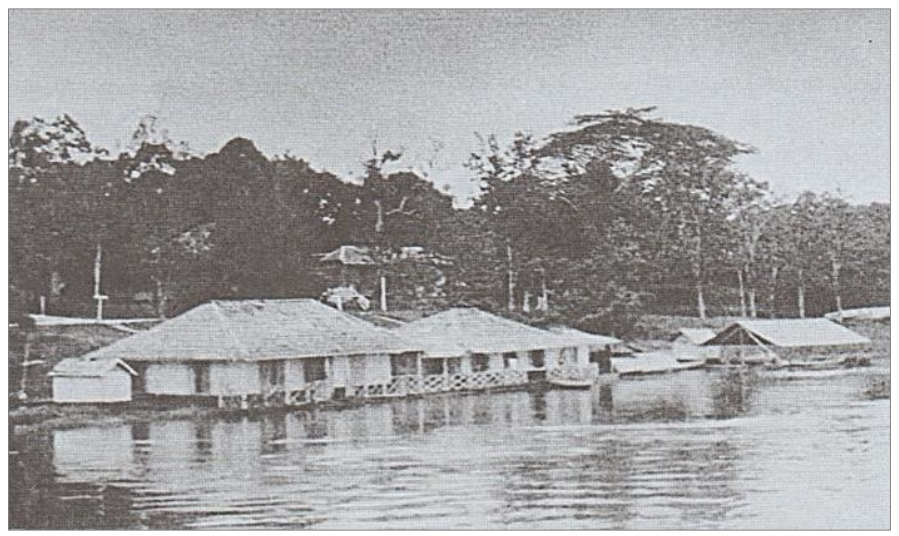

Figure 6. Floating hospital in Sintang, circa 1920. (Source: KIT Tropenmusium)

Japanese Occupation Era (1942-1945)

Although the Japanese occupation period in Indonesia was relatively short, this era had a significant impact on the lives of the people of West Kalimantan, including the lanting 
community in Sintang. As a consequence of the Second Sino-Japanese War during 19371945, the West Kalimantan region which had the highest Chinese population in Indonesia became the target of atrocities by the Japanese military government (Tze-Ken Wong 1998, Thurman \& Sherman 2001, Hui 2011). The Japanese advanced to Kalimantan was motivated more by political and territorial ambitions rather than economic factors (Siraishi 1993).

This period was also marked by the collapse of the economy, as Japanese military ruler used "hunger, terror \& lack of information" to defeat rebellions (Heidhues, 2003). Heidhues (2003:217) depicted the situation during the Japanese occupation as: "There was not a single boat that sailed on the Kapuas River". The climax was the Mandor Massacre, 1944, where tens of thousands of people, mostly Chinese and indigenous intellectuals, were executed (Ooi, 2011; Prabowo, 2019), while the rest fled to remote parts of Kalimantan. As the main rivers served as routes for military mobilization under Japanese control, many Chinese fled with their lantings, headed for small tributaries far to the remote inland region, hiding for survival (interviews, Sintang, 2018).

The number of lanting in Sintang declined drastically. During these dark period, lanting acted as a means of resistance for its inhabitants against the atrocities of the Japanese ruler. As expressed in Foucault's phrase: "Where there is power, there is resistance, and yet, or rather accordingly, this resistance is never in a position of exteriority in relation to power." (Foucault 1978:95).

\subsection{Post-colonial era}

\section{Early independence (1945-1965)}

Socio-environmental conditions in Kalimantan did not show drastic changes during the early years of the independence era compared to previous periods. Through Government Regulation (No. 64/1957) issued by President Sukarno, forest governance outside Java was handed over to local governments and overseen by provincial governments. This decentralization policy in the forestry sector during Sukarno's leadership was supported and shaped by political and economic strategies based on the idea of socialism that opposed the entry of Western investment. As a result, during the Sukarno era, both foreign and local entrepreneurs could not exploit forest resources excessively (Tolo 2013; Author's interviews, 2017).

In 1959, President Sukarno issued Government Regulation No. 10/1959, which intended to strengthen the national economy or the "indigenization" of the economy, by ordering foreign traders (including Chinese) not to practice their business outside the district capitals. The regulation forced them to move from small towns/villages to district capitals or to return to their home countries. The impact of the issuance of the law was very significant for Sintang, as a district capital. In a relatively short time, there was a dramatic increase in the number of lanting in Sintang as many Chinese traders from small towns/villages moved to Sintang with their lantings (interviews, Sintang, 2019).

The life of lanting people in Sintang continued to develop, becoming a prevalent lifestyle in the 1960s. At that time, almost all Chinese traders ran their shops from a lanting, selling rubber, among a number of other products. Rubber, for its part, has been considered a mainstay commodity in the Sintang market since around 1834, at the beginning of the Dutch era. Renowned for its high quality, Sintang's rubber was produced by the indigenous Dayaks, who came by their boats carrying raw rubber collected from inland forests, and was subsequently purchased by the Chinese traders (interviews, Sintang, 2018). 
In addition to serving as a primary means of transportation, rivers that are well maintained from an ecological standpoint can seamlessly become the lifeblood of the community that surrounds them because of their ability to provide an abundant source of clean water and fish for consumption. Because of this and for reasons of practicality regarding various other needs such as bathing, fishing, conducting business, and traveling, people considered living in lantings rather than on land (interviews, Sintang, 2018).

\section{New Order Era (1966-1998)}

Conditions changed under the New Order era of President Suharto. In terms of economic development, the exploitation of forest resources by the Suharto government has contributed to significant economic growth in Indonesia. However, from the other side, the granting of HPH (forest concession rights) and $\mathrm{HTI}$ (industrial forest plantations ) concessions to private and state-owned companies also causes a national disaster, due to the destruction of forest resources due to uncontrolled and consistently unsupervised exploitation. This has caused incalculable ecological losses, as well as social and cultural damage, including restrictions on access and eviction of community rights and the emergence of conflicts over the use of forest resources in the region (Nurjaya, 2005). During the Suharto era, Indonesia lost 40 million hectares of forest to palm oil plantations, transmigration areas through $\mathrm{HPH}, \mathrm{HTI}$, agricultural expansion, and illegal logging practices (Tolo 2013).

Damage to the forest and river affected the living conditions of locals, particularly the lanting community. Timber logging, gold mining, and massive land clearance for plantations caused numerous negative impacts, including water pollution, reduced fish population, and fear of the lanting being hit by timber logs, since rivers are used to flow timber from upstream to downstream, a method that is carried out in almost all watersheds of Kalimantan and lasts for decades because of its cheap cost (Person, 2008).

Due to the deteriorating condition of the river, in 1983, the Chief of Sintang District issued a regulation that appealed to lanting-dwellers, calling on them move from their lanting to land. As a result, the number of lanting decreased dramatically during this period, though they never completely disappeared (authors' interviews 2019), since river remained a more efficient transport medium, particularly for bulkier cargoes; it has been estimated that it required only $20 \%$ of the energy expenditure required for movement by land (Boomgard, 2007).

Another cause for the decline of lanting during this period was the issuance of regulations that prohibited local people from taking timber from forests that had turned into company concession areas. The government and business people treated timber as a high-value export commodity, while the lanting people were left without wood to build their houses or periodically replace old or damaged parts of their lanting. Because the local community was not well informed about the company's concession areas and continued to search for wood in the forest, many were captured and even killed by forest rangers (Authors' interviews, 2019).

\section{Reform era and today (1999-now)}

The Asian financial crisis and the economic collapse of Asian countries in 1997, followed by rapid political upheaval, forced President Suharto to finally step down from the presidency in May 1998. Later, decentralization policies implemented after to the fall of President Soeharto in 1998 devolved much political and economic autonomy to the regions (Sellato, 2015). Since then, there has been an opportunity to speak out against forest destruction and environmental exploitation. In this Reform era, some positive changes in policy and practice related to forestry issues have begun to emerge. However, the economic crisis also created new demands that 
have led to even more environmental destruction. This, in turn, has been exacerbated by an ambitious but chaotic decentralization process (Chidley 2002).

However, amid uncertainties, since the beginning of the 2000 s, the lives of lanting communities remain active. They have transformed and responded to the changes that have taken place in the increasingly urbanized Sintang city. Although land transportation and infrastructure have improved in West Kalimantan, largely replacing the dominance of water transportation, most of the villages in Sintang District and other remote areas still use river channels.

Today, lanting houses have a variety of functions (see Figure 7), which, in general, are intended to facilitate the mobilization needs of people in urban and rural-area river channels. Some lanting function as floating docks or boat jetties that rise and fall with the tides. Although the government has built docking facilities, many lanting owners also utilize their lanting as jetties and lease them on an hourly basis. Boats coming from upstream and downstream of the Kapuas River and its tributaries carry both passengers and goods to Sintang. The length of time for docking varies, ranging from hours to days or even weeks. Other lanting houses function as rest areas for boat passengers who stop for transit at Sintang. These rest areas consist of cafes, toilets, fuel kiosks, and platforms for loading and unloading of passengers. Floating rest areas are beneficial for boat passengers, particularly for mothers carrying babies or traveling with older people, since going ashore, particularly during low tide, can be difficult. Another different type of lanting for transit activities in Sintang is the floating inn. These relatively cheap lodgings are much bigger than traditional lanting houses because they have many bedrooms, toilets, a lounge, and a kitchen. Some of them are built as two-storey floating structures. The need for cheap lodgings came about from people living in rural areas, who often spend several days or weeks in Sintang, when taking care of errands. Some of these floating inns also serve as boarding places for students and workers from villages, who seek to continue their studies or work in Sintang, respectively.

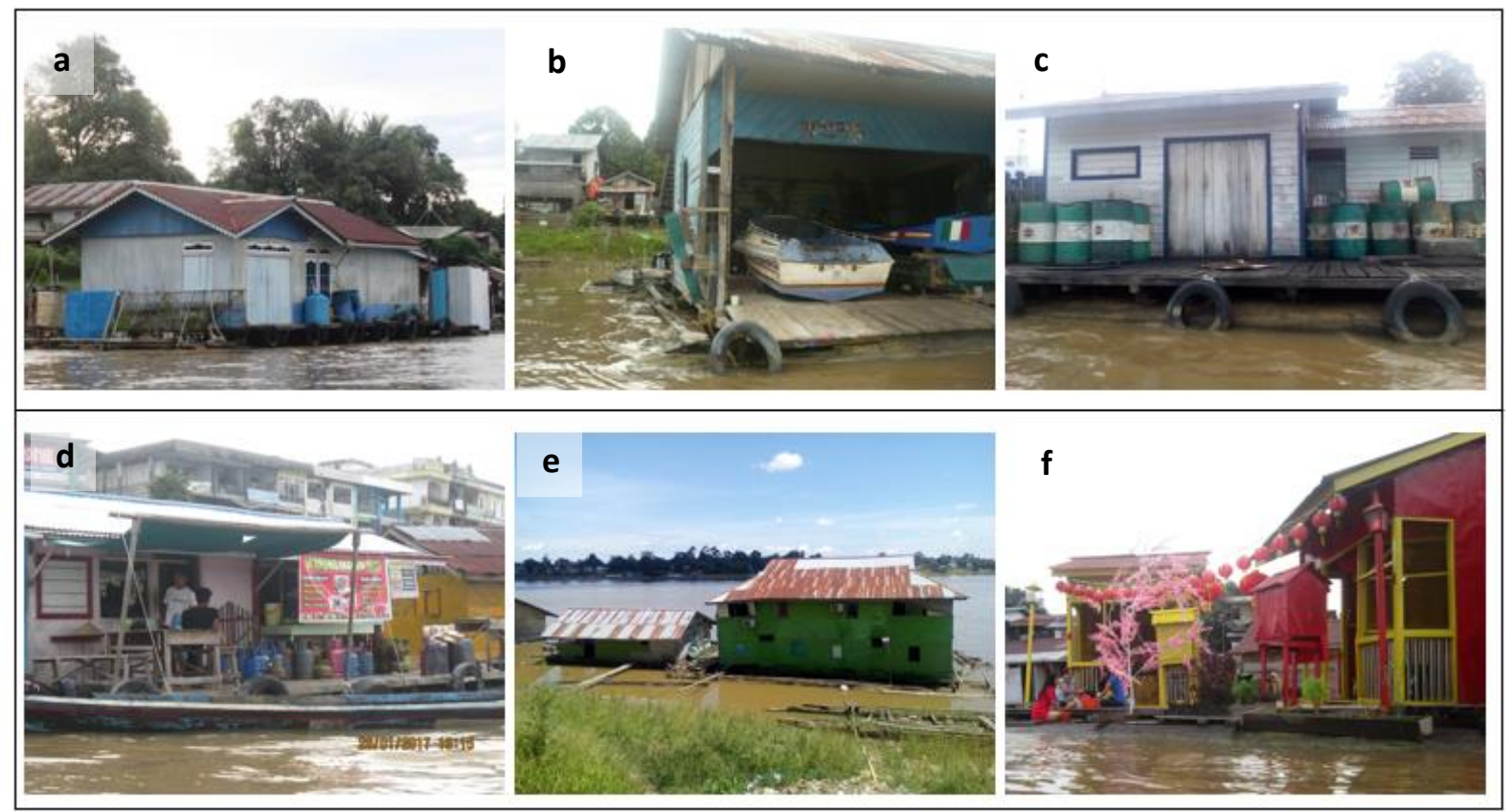

Figure 7. Various types of today's lanting houses: (a) residential, (b) speedboat garage, (c) fuel kiosk, (d) grocery kiosk, (e) inn/lodge, and (f) Chinese temple (Source: personal documentation 2017-2019) 
Several lanting houses also function as pop-up floating markets that are open at particular times, from early morning to noon. These floating markets are a strategic meeting place between urban and rural traders and consumers. Some have said that these markets resemble the vibrant river life of Sintang city in the old days. The floating markets have made it easy for people who come by boat since they do not need to go ashore. At the same time, they also benefit the Sintang residents, who buy fresh produce and fish products directly from the boats of the fishermen and farmers that come from the rural areas upstream. The floating market is also utilized as a loading and unloading dock for commercial goods. Apart from fresh produce and fishery products, the goods that are traded in this place vary greatly, including grocery items, gas cylinders, water gallons, parabolic antennas, and water tanks, among other things. Using flat-topped boats, they stack large items on the rooftops, tie them down with ropes, and bring them to the villages. These various forms of exchange activities illustrate the role of lanting in the urban-rural dynamics between Sintang and its surrounding town and villages, which use river transportation access. The dendritic river channels provide an important connecting network for the urbanization process in the interior of Kalimantan, and lanting, in this case, has become a transition place and a linkage between two different cultures, urban and rural.

\section{Connecting Past, Present and Future: challenges and opportunities}

To summarize the diachronic study, the timeline below shows the transformation of lanting over time and explained how factors such as power, economy, river networks, environmental changes, and natural resources/commodities, have implications for changes in function, conditions, and the life of the lanting inhabitants (see Fig.8).

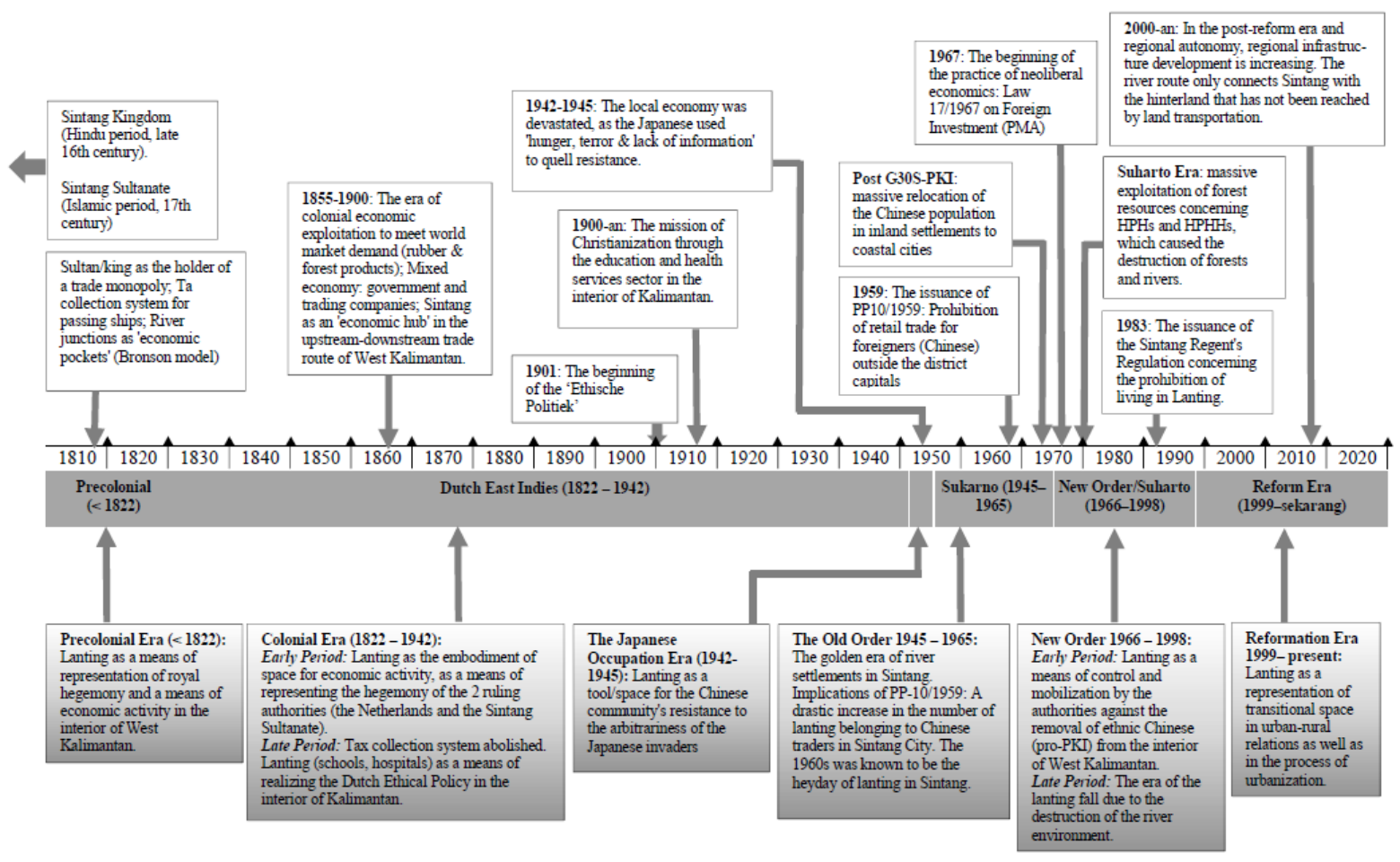

Figure 8. Timeline of the lanting's transformations over time (Source: Author's analysis)

Despite the continuity of lanting communities and their ability to contribute to the social and economic life of present-day Sintang, the decline of river conditions has resulted in concerns among lanting-dwellers. Massive deforestation for palm oil plantations has polluted and 
disrupted the hydrological cycle of the Kapuas and the Melawi rivers. Tidal patterns have become erratic, causing a drastic change in river water levels, which is dangerous for the stability of lanting structures. The supply of lumber for lanting material is increasingly scarce due to deforestation and illegal logging. Waste from palm oil plantations and from illegal mining has polluted the river and drastically reduced freshwater fish populations (Author's interviews, 2019). A study on raft houses in Thailand also concluded that the conditions of the inhabitants in the raft houses are insecure for today's living, and the existence of the raft house communities depends on the coexistence of the environments of water and mankind (Denpaiboon et al, 2002). Pye et al (2017) examined the relationship between land grabbing for plantations and rivers, proving that they not only take control of large tracts of agricultural land and forests, but also impair the social reproductive functions of rivers (fishing, drinking water, and washing). And what happened to the lanting community is much more than that. They are deprived of decent living space.

The lanting community is in a big dilemma. Moving to land to settle in landed houses has become a common consideration for many lanting-dwellers, but with the high price of land, competition with other urban dwellers, and limited financial resources, they have no choice but to continue their life in lantings, implementing various adaptation strategies to cope with the challenges of a changing river environment. Moreover, the issue of squatting has not been taken seriously in Indonesia because the flexible land law system has given the right to live in the city, or in other words, the kampongs in the middle of the city are 'permitted' by the government which is not willing to provide funding for public housing (Kusno, 2012). In all its limitations, lanting and its inhabitants continue to exist as a facet of modern urban life, playing a role in urban-rural social and economic linkage activities as well as in the urbanization process of Sintang city.

Lanting life nowadays is a form of community resistance to powers at various levels that tend to marginalize the inhabitants, such as the government with its policies and programs that tend to ignore the lanting settlements, or oil palm companies and gold miners which contribute to polluting rivers. This resistance includes a wide variety of actions and behaviors at all levels of human social life (individual, collective, and institutional) and in a number of different settings, including political system (Hollander and Einwohner, 2004). The urban-rural mobility pattern reflects the spatial expansion of the lanting community's living space. The lanting community is a social actor who constructs a new type of urban space, connecting Sintang and its hinterland, blurring the urban-rural dichotomy and, as stated by Ryoji (2007), articulating micro and macro societies where the lanting community are "agents on the move".

In the future, lanting settlements as floating structures could be a resolution for current problems where cities worldwide face the challenges of the rising sea level, extreme drought and flood, in context with the climate change. While cities in affluent countries are experimenting with sophisticated technological approaches, this study shows how some urban communities in the Global South have built their own capacity to respond to the dynamic environment and thus offer some opportunities to develop innovations based on knowledges, skills and resources that are deeply rooted in society.

\section{Conclusion}

This study has shown that lanting is an essential and inevitable element of the Sintang urbanism, and Kalimantan's riverine urbanism in general. It has experienced ups and downs since the beginning of its existence in the kingdom era until today. The role of large rivers and their tributaries which was vital in the past has placed the lanting in an important position for the early development of Sintang. The arrival of Chinese migrants as traders and miners in 
Kalimantan also had a big role in popularizing the lanting culture. The position of Sintang as the main authority in the interior and as one of the main economic nodes of the upstreamdownstream economic exchange path during the Dutch era, placed the lanting in the nexus of power, economy, and the distribution of commodities, on a broader scale. Despite experiencing dark times during the Japanese occupation era, where lanting functioned as a 'space of resistance' for local Chinese, lanting continued to survive and returned to its heyday in the 1960s. Suharto's neoliberal policy, which was contrary to Sukarno's anti-foreign investment policy, then placed lanting in a contrasting situation, where environmental damage, especially river's deterioration, had a major impact on the lacking quality of life of the inhabitants. Nevertheless, lanting have never really disappeared. Today the lanting people often become subsumed under circumstances of informality, because the constitution of urban society in Indonesia is often characterized by extreme conditions of single duality-like two faces of a coin-such as modern-traditional, formal-informal, and capitalist-bazaar (Harjoko 2017). This Western analysis classified the duality of this society as a dichotomy, wherein the structure of duality is merged into a relatively singular capitalist society. They are not a dichotomy, but rather form two structures of society with respect to values and norms, which coexist in space. Today, rapid land-oriented urban development has triggered the process of urbanization, and Sintang's lanting continue to play a significant role in urban-rural socioeconomic linkages through the river's dendritic networks.

It must be admitted that this study has not provided an equal proportion in each historical period, because in Indonesian historiography, there are periods, especially the 1950s, which are considered terra incognita, since only a small part of the archipelago had been studied by scientists at that time (Bemmelen \& Raben, 2011). This continued until the fall of the New Order era. The Reforms era have given a major impetus to increased interest and attention to the 'region', as well as to regional history studies (Ibid., 2011). For future studies, it is hoped that there will be more references to further deepen studies on lanting and urbanism in Kalimantan. However, with all its limitations, this study allows planners to understand that many of our so-called contemporary "problems" are actually part of a long-term process and not simply a generalized product of current trends. Thus, it is important to learn to see contemporary cities in Kalimantan as manifestations of complex inter-related social, political and ecological forces that shaped the struggles of the present, in order to gain a better understanding and to conceptualize the urbanism of Kalimantan cities.

\section{Acknowledgments}

I would like to express my sincere gratitude to my research supervisors, for their patient guidance, enthusiastic encouragement, and useful critiques of this part of my doctoral research work. I would also like to thank S. Djalil and Albertus for their advice and assistance during the process of data collecting. My grateful thanks are also extended to colleagues and staff in the department for their support.

\section{References}

Balibar, E. (2007). Justice and Equality: A Political Dilemma? Pascal, Plato, Marx. Published by: Mahanirban Calcutta Research Group Salt Lake City Kolkata - 700106 India Web: http://www.mcrg.ac.in

Bemmelen, S. \& Raben, R. (Eds). (2011). Between Regions and Countries: Indonesia in the 1950s [Antara Daerah dan Negara: Indonesia Tahun 1950-an]. Jakarta: Yayasan Obor Indonesia.

Bronson, B. (1978) Exchange at the Upstream and Downstream Ends: notes towards a functional model of the coastal state in Southeast Asia. In: Economic Exchange and 
Social Interaction in Southeast Asia. Edited by: K. Hutterer. Ann Arbor: University of Michigan Papers on South and Southeast Asia No.13: 39-54.

Chidley, L. (2002) Forests, people, and rights: A down to earth special report. London, UK: Rainforest Foundation,.

Cleary, M. and P. Eaton. (1992) Kalimantan change and development. Singapore: Oxford University Press,.

Christie, J. W. (1995) State formation in early maritime Southeast Asia; A consideration of the theories and the data. Bijdragen tot de Taal-, Land- en Volkenkunde 151, no: 2, Leiden, 235-288.

Derek Heng Thiam Soon (2001). "The Trade in Lakawood Products Between South China and the Malay World from the Twelfth to Fifteenth Centuries AD". Journal of Southeast Asian Studies. 32 (2): 133-149. doi:10.1017/S0022463401000066. S2CID 162474082.

Denpaiboon, C., Tohiguchi, M., Matsuda, H., Hashimoto, S. (2002) Typology and Life Style Analysis of the Raft House (Ruan Pae) in Riverine Settlements in Thailand. Journal of Architectural Research and Studies Vol.1. 2002. Faculty of Architecture Thammasat University.

Evers, H. (2015). Kampung Air: Water Settlements on the Island of Borneo. Journal of the Malaysian Branch of the Royal Asiatic Society, 88(1 (308)), 79-85. Retrieved August 23, 2021, from https://www.jstor.org/stable/26527694

Fienieg, A. (2007) The history of Sintang: a collection of books, manuscripts, archives, and articles. Amsterdam, The Netherlands: Koninklijk Instituut voor de Tropen (KIT) (Royal Tropical Institute, RTI).

Harjoko, T. J. (2017). I DWELL In [Im]possibility: Utopian Planning \& Design in Indonesia Toward a City of One Dimensional Society. Paper presented at The 15th International Conference on Quality in Research (QiR 2017), Bali, Indonesia. http://qir.eng.ui.ac.id/wp-content/uploads/2017/03/Proceeding-of-the-15thInternational-Conference-on-QiR.pdf

Heidhues, M. S. (2003) Golddiggers, Farmers, and Traders in the "Chinese Districts" of West Kalimantan, Indonesia, Ithaca, NY: Cornell University, Southeast Asia Program Publications.

Hellman, J. (2018). How to Prove You are Not a Squatter: Appropriating Space and Marking Presence in Jakarta. In Cabannes Y., Douglass M., \& Padawangi R. (Eds.), Cities in Asia by and for the People (pp. 41-68). Amsterdam: Amsterdam University Press. doi:10.2307/j.ctv7xbs0b.5

Hollander, J., \& Einwohner, R. Conceptualizing Resistance. Sociological Forum, 19(4), 533 554. 2004. Retrieved January 5, 2021, from http://remotelib.ui.ac.id:2063/stable/4148828

Hui, Y.F. (2011). Strangers at Home: History and Subjectivity among the Chinese Communities of West Kalimantan, Indonesia. BRILL. pp. 43-. ISBN 978-90-474-2686-8.

Keyfitz, N. (1961) The ecology of Indonesian cities. American Journal of Sociology 66:348354.

Khee Giap Tan; Merdikawati, N., Amri, M., Berger, B. H. (2015). 2014 Annual Competitiveness Analysis and Development Strategies for Indonesian Provinces. World Scientific. pp. 286-. ISBN 978-981-4730-43-3.

King, R., \& Idawati, D. (2010). Surabaya Kampung and Distorted Communication. Sojourn: Journal of Social Issues in Southeast Asia, 25(2), 213-233. Retrieved August 23, 2021, from http://www.jstor.org/stable/41057097

Kusno, Abidin. (2012) Politik Ekonomi Perumahan Rakyat dan Utopia Jakarta. Yogyakarta: Penerbit Ombak.

Lefebvre, Henri. (1991). The Production of Space, Translated by Donald NicholsonSmith, Oxford: Blackwell. 
Listiana, D. (2012) Tanah Sintang Masa Kolonial: telaah sederhana tentang perubahan status pemerintahan dan wilayah kekuasaan [Sintang during Clonial: a short study of changing status of government and territory]. Pontianak: STAIN Pontianak Press,.

Nurjaya, N. (2005). Sejarah Hukum Pengelolaan Hutan di Indonesia. [History of Forest Management Law in Indonesia]. Jurisprudence, Vol. 2, No. 1, Maret 2005: 35-55.

Ooi Keat Gin (2004). Southeast Asia: A Historical Encyclopedia, from Angkor Wat to East Timor. ABC-CLIO. pp. 271-. ISBN 978-1-57607-770-2.

Ooi Keat Gin. (2011) The Japanese Occupation of Kalimantan, 1941-1945. Routledge 270 Madison Ave, New York, NY.

Oostindie, G. (2008). Dutch Colonialism, Migration and Cultural Heritage: Past and Present. BRILL. pp. 292-. ISBN 978-90-04-25388-9.

Person (Ed.) (2008) Hutan Dihabisi, Banjir Makin Menjadi-jadi. Retrieved December 05, 2020, from

https://edukasi.kompas.com/read/2008/09/20/07201186/hutan.dihabisi.banjir.makin. menjadi-jadi?page $=$ all

Prabowo, M. R. (2019). Peristiwa Mandor 28 Juni 1944 di Kalimantan Barat: suatu pembunuhan massal di masa penduduk Jepang [The Mandor Incident 28 June 1944 in West Kalimantan: a mass killing during the Japanese occupation]. Bihari: Pendidikan Sejarah dan Ilmu Sejarah, 2 (1) 2019.

Pye, O., Radjawali, I \& Julia (2017) Land grabs and the river: eco-social transformations along the Kapuas, Indonesia, Canadian Journal of Development Studies / Revue canadienne d'études du développement, 38:3, 378-394, DOI:10.1080/02255189.2017.1298518

Rahmayani, A., Y. Darmadi, and A. Firmansyah A. (2018) Dari Hulu ke Hilir: Integrasi Ekonomi di Sungai Kapuas pada 1900-1942 [From upstream to downstream: economic integration in the Kapuas River in 1900-1942]. Yogyakarta: Diva Press,.

Ryoji, S. (2007) People on the Move: Rural-urban Interactions in Sarawak. Kyoto: Kyoto University Press.

Schliesinger J. (2017) Early Seafaring and Maritime Trade in India and Southeast Asia. White Elephant Press.

Sellato, Bernard. (2015) Sultans' Palaces and Museums in Indonesian Kalimantan: National Policies, Political Decentralization, Cultural Depatrimonization, Identity Relocalization, 1950-2010. Archipel. 89(2015). 125-160. 10.4000/archipel.494.

Sjamsuddin, H., and M. Nursam. (2013) Perlawanan \& perubahan di Kalimantan Barat: kerajaan Sintang, 1822-1942 [Resistance \& change in West Kalimantan: Sintang kingdom, 1822-1942]. Yogyakarta: Ombak.

Soja, E. (1980). The Socio-Spatial Dialectic. Annals of the Association of American Geographers, 70(2), 207-225. Retrieved August 23, 2021, from http://www.jstor.org/stable/2562950

Sumarman, G. (2010) Dua abad Tiong Hoa di Sintang. Lothay-Kapitan (Kapitan Der Chineezen) Pantha Rei: Catatan Dan Kliping [Two Ages of Tiong Hoa in Sintang. Lothay-Kapitan (Kapitan Der Chineezen)]. 2010. [online] URL: opiniherry.blogspot.com /2010/12/2-abad-tiong-hoa-di-sintang-lothay.html

Tagliacozzo, E. and Chang, W.C. (2011). Chinese Circulations: Capital, Commodities, and Networks in Southeast Asia. Duke University Press. pp. 236-. ISBN 978-0-8223-49037.

Thurman, M. J. and Sherman, C. (2001). War Crimes: Japan's World War II Atrocities. Turner Publishing Company. pp. 123-. ISBN 978-1-56311-728-2.

Tolo, E. Y. S. (2013) Sejarah ekonomi politik tata kelola hutan di Indonesia [History of the Political Economy of Forest Governance in Indonesia]. Harian Indo Progress. 2013. [online] URL: indopro-gress.com/2013/12/sejarahekonomipolitiktatakelolahutandi indonesia/

Veth, P. J. (2017) Kalimantan Bagian Barat: geografis, statistis, historis [Western Kalimantan: geographical, statistical, historical]. Pontianak: Institut Dayakologi. 
Wertheim, W. F. (1950) Effects of western civilization on Indonesian society. Honolulu, Hawaii, United States: International Secretariat, Institute of Pacific Relations.

Wikipedia Foundation. (2021, August 2). Daftar Sungai di Indonesia [List of Rivers in Indonesia].Wikipedia. https://id.wikipedia.org/wiki/Daftar_sungai_di_Indonesia. 